\title{
PII- Potential Innovation Index: a Tool to Benchmark Innovation Capabilities in International Context
}

\author{
Daniel Galvez, Mauricio Camargo, Julio Rodriguez, Laure Morel
}

\begin{abstract}
Benchmarking has become a useful tool for companies, enabling better decision-making and improvement of internal practices towards world-class performance. Nevertheless, concerning SMEs' innovation capabilities from traditional sectors, benchmarking applications have been scarce. This article uses a predefined metric named the "Potential Innovation Index (PII)", based on internal practices of the firms to compare innovation capabilities of two groups of similar SMEs from 2 different geographical, cultural and social contexts. Results were used to analyze similarities and differences, strengths and weaknesses of the groups. Obtained results confirm the difficulties to innovate of this type firms, no matters the sector or country, as over $55 \%$ of the companies studied were evaluated as having a low innovative performance. However, regarding the index's constitutive practices, significant differences were found. Which leads to infer that innovation support strategies to enhance innovation must be adapted to the local context and culture.
\end{abstract}

Keywords: Benchmarking; innovation capabilities; Potential Innovation Index; SMEs; innovation practices.

Lorraine University / ERPI (Equipe de Recherche des Processus Innovatifs), 8, rue Bastien Lepage

54010 Nancy Cedex, France. Corresponding author, e-mail: daniel-andres.galvez-manriquez@univ-lorraine.fr 


\section{Introduction}

It is a fact that innovation drives the firms to a superior competitive level. In the long run, it is technological innovation capability that constitutes a major source of competitive advantage. (Guan et al. 2006). Innovation has been described as "the engine that drives revenue growth" and considered as the basis for organizational survival. So there is a need to understand the mechanisms driven the innovation process in order to manage it, and then support a continuous growth of the companies. However, this is a complex process depending on several factors and stongly influenced by context and sectoral features. These last years, a body of knowledge has been developped on the understandig of the innovation drivers and metrics(Milbergs 2004; Muller, Välikangas, and Merlyn 2005; Zawislak and Marins 2008). Firms are prone to benchmark their current practices versus other firms about several performance measures, innovation performance included. In 1979 Xerox fulfilled for the first time the benchmarking based on the comparison of the best practices, from this moment his application has expanded to various areas of operation inside the companies (Hurmelinna et al. 2002; Lai, Huang, and Wang 20II; Rorissa, Demissie, and Pardo 20l I). The benchmarking has been positioned as a useful tool of analysis for different organizations allowing the identification, comprehension and adaption of the practices and processes related to the organizations helping to improve the results and performance (Jarrar and Zairi 200I). At present, the benchmarking has a diversified field of applications, among them the area of supply chain (Garcia et al. 2012) and manufacturing (Herzog, Tonchia, and Polajnar 2009) could be underlined. A domain in which the benchmarking has not been very used is the innovation inside the companies, although there are some works that have tried to realize a few first approaches (Radnor and Robinson 200I).

Nevertheless, in innovation practices, benchmarking applications have been scarce. In part, this lack can be explained by the difficulty to measure innovation capability by mean of innovation practices, as those metrics correspond to the intangible actives of the companies. Measuring innovation level of an enterprise is a complicated and difficult task due to the complexity of the processes and the effort needed to of establish the variables to be measured. Innovation is a transverse characteristic inside the companies, having a multicriteria dimension (Chiesa, Coughlan, and Voss 1996; Guan and Ma 2003). In recent years many studies have attempted to overcome this need to measure innovation capability (Cheng and Lin 2012; Igartua, Garrigós, and Hervas-Oliver 2010; Rodrigues, Fernandes, and Martins 2006). The evolution of innovation metrics aimed at measuring innovation related to the processes and practices involved in it instead to the dedicated resources (inputs) or new products (outputs) (Milbergs 2004; Muller, Välikangas, and Merlyn 2005a). Within this framework is the methodology proposed by (Morel and Camargo 2006), who defines the calculation of a potential innovation index IIP based on multi-criteria evaluation of six criteria to evaluate the innovation capabilities within companies (creativity, new product development, Human resources management, strategy, project management and knowledge management). According to their IIP the companies can be classified into 4 categories (Proactive, Preactive, Reactive, Passive), following a typology proposed by (Godet 1997) to explain the strategic vision of a company into its market. So given this framework of innovation metrics, our main research question is: how does the IIP enables to compare the innovative capabilities between two different contexts?

This article seeks to use the IIP as a benchmark for comparison competitive between two groups of companies similar to each other but from 2 different geographic areas, to analyze similarities and differences, strengths and weaknesses of the groups. The first group consists of SMEs in France while the second by its peers in Argentina.

Among the results the main similarity between samples in that for both countries over $55 \%$ of the companies studied were evaluated as belonging to the low innovative category (Passive). However, the performances of the innovation capabilities are different, since the Argentinian companies support an equal level between the evaluated practices, while the French companies promote clearly the strategy in decline of other practices. In order to expose our proposal, the present article has the following structure: section 2 reviews the state of the art of measuring innovation capabilities in companies and the use of benchmarking as a tool of analysis. The section 3 presents the framework for measuring innovation capability to be used as a benchmark. The section 4 describes the methodology and characterizes the study groups. The section 5 shows the analysis and results. Finally, a discussion of the potential limits and prospects of applying benchmarking in the field of innovation in the companies is presented.

\section{Literature review}

\section{Benchmarking}

The benchmarking is a tool of evaluation of products, services or processes within a group of organizations with common characteristics, in order to determine the organization best evaluated inside the area of study and to transmit this knowledge to the group. This better evaluation is named as best practice. 
Since the seminal work of (Womack, Jones, and Roos 2007), the benchmarking has been applied to different fields of study such as (Phylipsen et al. 2002) who proposed a benchmarking of the energy efficiency in the Dutch Industry. The supply chain is a topic widely discussed inside the studies of benchmarking, (Rizet et al. 20I2) analyzes the supply chain in European companies particularly his $\mathrm{CO} 2$ emission. Another topic studied is the transport, (Henning et al. 20l I) takes a benchmarking applied to the transport in New Zealand. The benchmarking in recent years has been emerging in new topics of study, most notably in marketing (Akdeniz, Gonzalez-Padron, and Calantone 2010).

To make the benchmarking process is indispensable to assess the organizations' performances, regarding a set of metrics and thus compare them. This is the principal reason why the benchmarking has not been more used in the innovation area, since there is la lack of a widespread accepted or common metrics to measure the innovation capabilities. Currently benchmarking applications have been developed in some specific innovation practice and not of global form. For example, (Griffin 1997) looks for the best practices in the development of new products, (Hurmelinna et al. 2002) analyzes high-tech Finnish companies determining the best practices for the success of R\&D in buyer-supplier relationship. In United Kingdom (Radnor and Robinson 200I) makes the benchmarking based on the presence or absence of personal aspects, cultural aspects and process aspects that will support the innovation in a group of companies. (Feeny and Rogers 2003) creates an indicator to measure the innovation capability of the Australian companies. More recently, (Cagliano et al. 20l I) show that it is possible to explain different patterns in the adoption of new forms of work organization practices when considering company size and cultural variables. Also, (McAdam et al. 20I0), based on a comprehensive benchmarking study in the UK, proposes a innovation model for SMEs determining the innovation practices to be measured, but without defining metric associated.

\section{Innovation management in SMEs}

The innovation management has taken a fundamental role in the progress of SMEs, because it present competitive advantages to the companies in relation to his market. The development of the area of innovation allows to a company to be prepared to face the current industrial world that changes permanently. Among other things, the innovation management gives to the products of the company the added value that will make differ from his competition and gain competitive advantages (Roper and Arvanitis 20I2). The innovation in the companies can be defined as a great workgroup, therefore the creation of networks (universities, centers of investigation, etc.) and business cooperation is crucial (Yo- guel and Boscherini, 1996). Definitively it is possible to affirm that the innovation has a positive effect in the growth and development of the companies (Boly 2004; Love, Roper, and Bryson 20I I; Zawislak et al. 20I2).

Hughes (200I) concludes that, for the growth based on the innovation in companies of the UK, the management abilities are more important than the financial factors. (Rosenbusch, Brinckmann, and Bausch 20II) suggests that the innovative SMEs are more successful, and that for his relevancy in the global economy is necessary the development of the innovation capabilities of this companies type.

To manage the innovation capabilities the first step is to be able of measuring this characteristic, therefore, the creation of metrics or methods to measure this capacity in the companies is crucial, to determine the current condition of the company and define a strategy improvement. Many investigations seek to determine the best form of evaluation of the innovation, (Milbergs 2004; Muller, Välikangas, and Merlyn 2005) realize a literature review, analyzing the evolution of the innovation metrics and defining new metric focusing on the measurement of the innovative processes. Other authors affirm that the innovation within companies includes different areas, therefore the best way of measuring the innovation capabilities is by proposing and solving a multicriteria problem (Feeny and Rogers 2003; Rodrigues, Fernandes, and Martins 2006). (Adams, Bessant, and Phelps 2006) realizes a bibliographical analysis of different propositions to measure the innovation in the SMEs and puts in evidence that at present the best way of measuring the innovation capabilities is using a multicriteria approach. The definition of metrics or a method provides the basis for benchmarking, since it delivers the possibility of measuring the companies under the same criterion.

\section{Methodology for measure innovation capabilities}

The data gathering methodology is based in this proposed by (Corona 2005) who defined an potential innovation index (PII), which is calculated using Multi criteria Decision Making Tools, and uses as criteria a set of innovation practices defined by (Boly 2008). These practices are concrete actions executed by the enterprises to define their strategy, to guide and to impel the innovation processes and to make evolve the organization or its methods of work. After further research work, (Assiélou 2008; Morel and Boly 2008; Rejeb et al. 2008; Sepulveda et al. 2010; Nemery et al. 2012; Boly et al. 2013).A general referential framework of internal innovative practices for an ideal company has been proposed. So, the assessment of a questionnaire to evaluate a firm practices and the subsequent level of IIP, enables decision maker to compare the firm results with the referential. 
The methodology defines, six main innovation practices (IP), subdivided into 18 sub-practices (see Table I), and their associated importance (wi) which have been defined based on a bibliographic investigation and a consultation with innovation experts. Note that the list can be enhanced or modified as new innovation management practices emerge.

\section{IP I. Creativity and Concept Genera- tion $(w I=0.175)$}

a) Use of tools to increase the creativity

b) Integration of the clients and suppliers in the conception process

c) Organization, compilation and management of information from the exterior

\section{IP2. New Product development (w2 = 0.107)}

a) Use of advanced tools for design aid

b) Existence of a methodology to the design process

c) Hardware Equipment

IP3. Human Resources Management (w3 = 0.068)

a) Management of competences and the skills of the society

b) Innovation stimulation

IP4. Technological Strategy ( $w 4=0.232$ )

a) Strategy integrated to favor the innovation

b) Network operation

c) Client Importance

d) Financing

IP5. Project Management ( $w 5=0.194)$

a) Project administration

b) Management of project portfolio

c) Organization of tasks tied to the Innovation

IP6. Data and Knowledge Management (w6 = 0.224)

a) Continuous Improvement of the innovation process

b) Politics of Management of the intellectual property

c) Knowledge Capitalization

Table I : Six innovation practices and its weights

Multicriteria computation of the index follows a flow-sort algorithm as described in Nemery (2012), which uses the firm's answers of the form, and the set of weights described in Table I. Once the IIP index obtained for the set of evalu- ated firms, its value allows decision maker to sort the firms by innovation performance in a classification created by (Godet 1997), according to the nature of its system of innovation, and classifies companies in four categories: Proactive, Preactive, Reactive and Passive. Each category describes a strategic vision of the firm, as follows.

* "Proactive" are the most dynamic and most offensive companies, these who create technological changes in a long-term vision. It results from it a control by these last ones of the competitive environment.

* "Preactive" are companies that don't ignite the changes, but which anticipate them by he use of a very active system of technology watch. It is also dynamic and offensive companies but having a strategic vision with average term.

* "Reactive" are companies which react to the dynamics of their environment. This means that the only technological change drivers become from concrete demands from the market. Their vision of economic planning is short-term.

* "Passive" are companies which adopt a defensive attitude in front of disturbances of the environment, that is to say that they think only of surviving.

The importance of this classification is that it enables entrepreneur's awareness on their real engagement to innovate and define internal strategies to improve their category. Moreover, the methodology will enable policy makers to benchmark companies at sector o regional level to define industrial policies or support ressources allocation.

\section{Research Sample}

The companies used for this study were evaluated in their innovation capabilities using a questionnary following the methodology exposed in the section 3 , the data collection for the evaluation is gathered by means of a visit to the company where there is realized an interview with the director of the company or any representative thereof. The interview have an average duration of one hour. The companies evaluated are divided in two groups; the Argentinian companies and the French companies.

The Argentinian group is composed by 34 companies located to the North-East of the country (NOA region), they represent $52 \%$ of the total of companies used in this study. The French panel consists in 32 companies; all of them are located in Lorraine's region ( $48 \%$ ).

\section{Argentinian sample}

Of these 34 firms, 20 are older than 15 years and only 6 are younger than 5 years. The average number of employees is of 36 for company; being 130 the greatest and 7 the minor

ISSN: 07 I8-2724. (http://www.jotmi.org) 
number of employees. From the current panel, 18 of the 34 firms are family managed. As shows the figure I the Argentinian companies come from two activity sectors; 25 work in food industry and 9 at construction.

\section{French Sample}

From the French panel, 3 firms have less than 5 years' operating and only 15 have more than 15 years. The average number of employees is of 22 for company; being 143 the greatest number of employees and only 3 the minor. The companies belong to different sectors from activity, the figure 2 shows that most of the companies is of woodwork, while the rest divides in 5 activity sectors in similar quantities (the construction, the industry of food, the metallurgy, the industry of wood, others).

\section{Benchmarking and Analysis}

\section{Global analysis}

As shown by Figure 3, when comparing groups of studies it is possible to verify that in both countries over $55 \%$ of the companies are classified at the lower level of innovativeness (Passive). Only 5\% were classified as Preactive and there are not proactive firms.

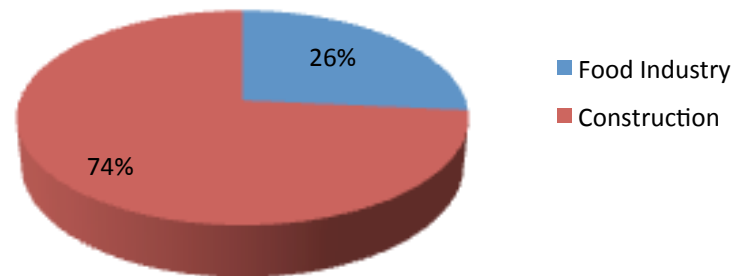

Figure I. Sector participation for the Argentinian sample

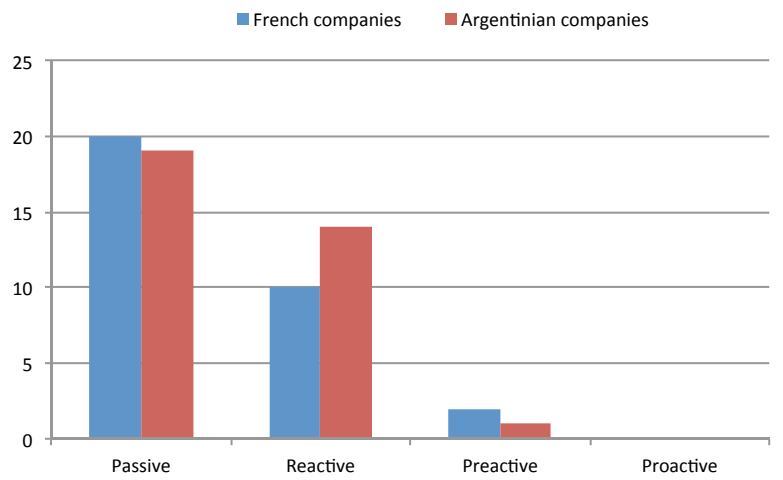

Figure 3. Classification of innovativeness level by category and country
Figure 4, shows an overview of SMES the panel, as it compares the IIP index and the size of the firm measured by the number of employees. It provides evidence that there is a correlation between the company size and the PII index. Three different clusters are identified.

- $\quad$ a first group, of small firms under 50 employees. Most of them are classified as been Passives, with lower level of PII

- $\quad$ a second group, of greater SMEs, between 50 and I50 employees. These companies are classified within the Reactive and Preactive categories and there are not Passive firms within this cluster.

- $\quad$ a third cluster, of small very innovative companies, under 50 employees. Classified within Reactive-Preactive categories.

Regarding the geographical context, there is no significant differences between both countries, as the average IIP for the French companies is of 0.266 and for the Argentinian companies is of 0.262 . However, when looking the values for the main innovative practices (Figure 5), some differences appear.
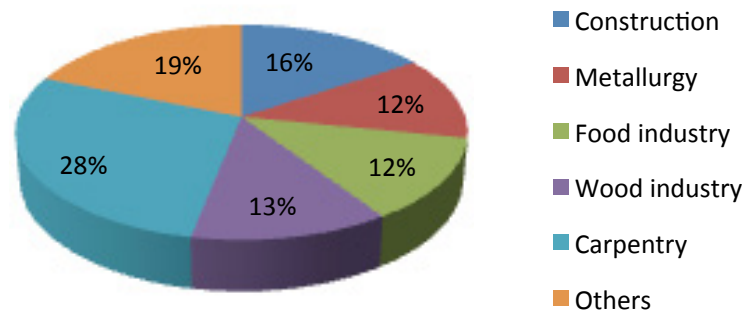

Figure 2. Sector participation for the French sample

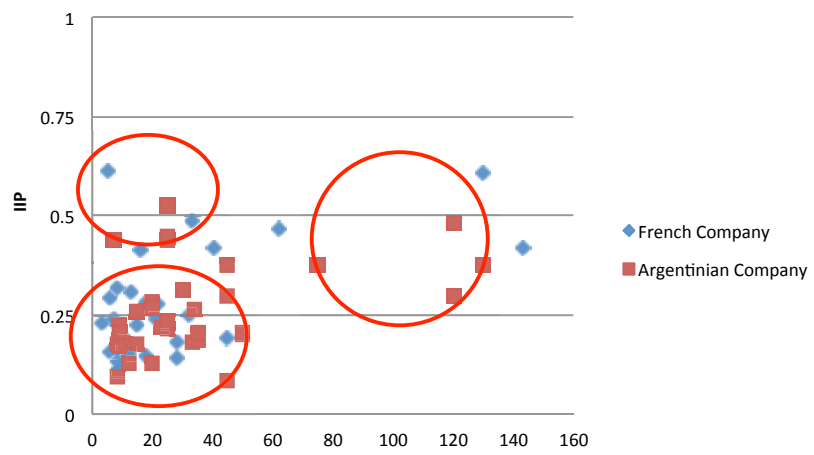

Figure 4. PII index and category vs. enterprise size (number of employees)

ISSN: 07 I8-2724. (http://www.jotmi.org) 
The average Argentinian companies shows rather similar level for the 6 evaluated practices, where creativity is a strong point and knowledge management is a weak point. On the other hand, the French companies show a mixed performance between their practices, emphasizing strategy as the strongest practice.

It is in the strategy practice where the French companies make a major difference in comparison with the Argentina's companies. While the 5 remaining practices show similar levels between both groups of study.

Another way to compare both groups is to analyze the average evaluation of each of the six practices, taking the group of Argentinian companies as a base of comparison (axis y).

As shown figure 6, it is possible to see a clear difference in favor of the French companies in the strategy practice, which is the best evaluated on average sound by 45 $\%$ than their counterparts in Argentina. For the Argentinian companies realize the counterweight the practices of new product design and project management with $14 \%$ and $23 \%$ respectively. In the three remaining practices the differences are minimal.
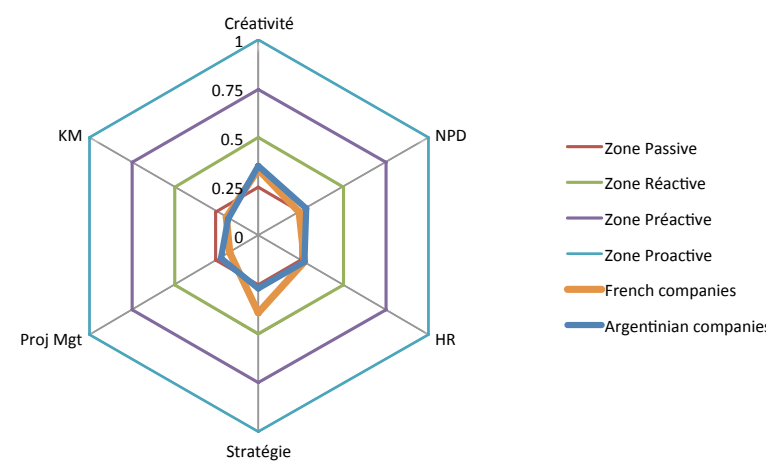

Figure 5. Innovative practices values for French and Argentinian SMEs

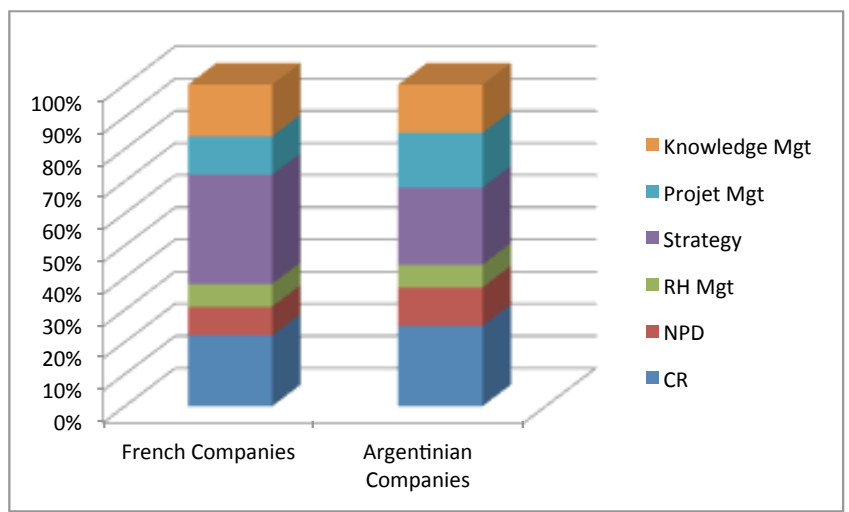

Figure 7. Composition of the PII for the French and Argentinian companies.
The evaluated criteria have different importance on the calculation of the IIP, therefore, his contribution from the innovation capabilities of the company is different too (figure 7). The French companies base their innovation capabilities on the strategy practice that contributes with $34 \%$ the innovation index, while creativity contributes $22 \%$, both represent little more than half of the innovation potential of the companies. For Argentine companies strategy and creativity stand out as the practices that reach in major degree to the calculation of the innovation index, with $24 \%$ and $25 \%$ respectively.

The innovation potential index composition varies for the two groups, the Argentine companies emphasizes a major homogeneity between 6 evaluated practices, while in the French companies highlights as strong point strategy practice.

\section{Analysis for innovation practice}

Figure 8. values for innovative practices: Argentinian sample. In this box plot, for each practice the best evaluation, the worst evaluation, the average and the standard deviation of the group are plotted. The Argentinian companies show a

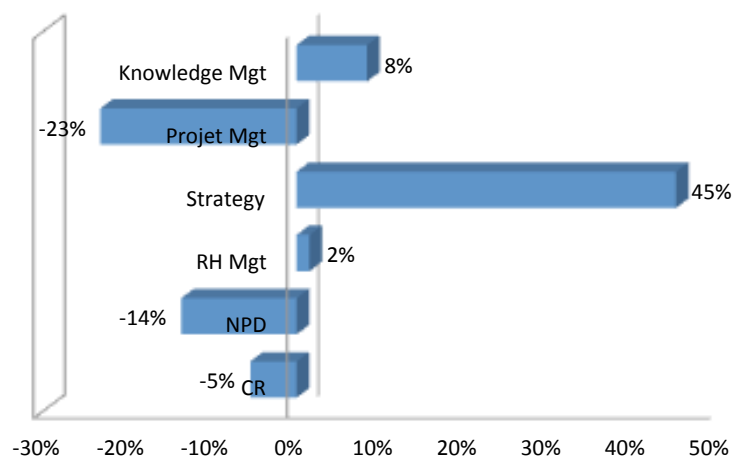

figure 6. Percentage difference for practice of the French companies in relation to the Argentinian companies (axis, 0\%)

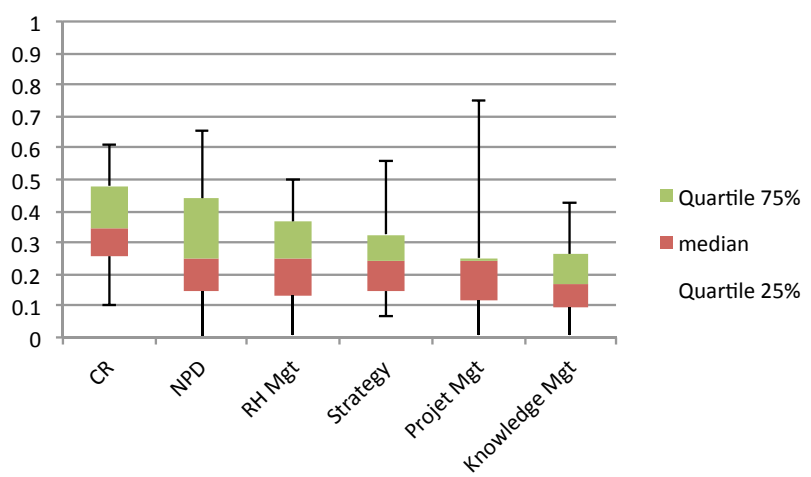

Figure 8 shows the behavior of the group of Argentina's companies for each of 6 innovative practices.

ISSN: 07 I8-2724. (http://www.jotmi.org) 
homogeneous behavior, except in the practices New Product Development and Project management, nevertheless they present a higher dispersion degree. Another point to note is that in the project management practice there is an enormous difference between the best evaluated company 0.75 and the average of the group 0.24 , this increases furthermore his dispersion. In addition, $75 \%$ of the evaluations in project management is practically under the median, which means that the dispersion is produced only for the 25 $\%$ of the companies better evaluated in this practice, which moves between 0.25 and 0.75 .

If the same analysis is realized in the French group the following graph is obtained.

The French companies shows a different behavior than their peers in Argentine, except in the creativity practice where major differences are not seen. In the 5 remaining practices the French companies have a greater dispersion, especially in the NPD practice that shows the greater standard deviation. On the strategy practice the French companies cover practically the whole range of evaluation, since the worse evaluated company is with 0.05 , while the best obtains 0.95 . This biggest difference between the behaviors of the French companies could be explained because they come from a bigger variety of activity sectors. Finally, in most practices evaluated it is possible to estimate that the first two quartiles are very compact, while the dispersion begin to increase when going to $3 r d$ quartile and overcoat in the four quartile where they find the better evaluated companies. This could imply that the dispersion observed in the evaluations of the French companies is produced largely by the better evaluated companies.

\section{Conclusion}

One of the principal conclusions that can be obtained from this benchmarking is that without importing the geographical environment, all the SMEs of traditional sectors have a very low level of innovation. Of the total of companies studied in this article, $95 \%$ is classified inside in the two lowest categories of innovation, and over $55 \%$ in the worst category. Only 3 of 66 companies achieve a level in innovation of regulating to well. One of the causes to which we can attribute this low level of innovation is the size of the companies. Another common point that shows the studied groups is that, with few exceptions, there is a direct relation between the number of employees of the company and his innovation level, that is to say, a larger company presents a greater development of their innovation capabilities. The identified clusters in figure 4 , give us some evidences that a higher level of innovation on SMEs whit a greater number of employees is related to a major degree of formalization in their managerial processes. Also there is a small company

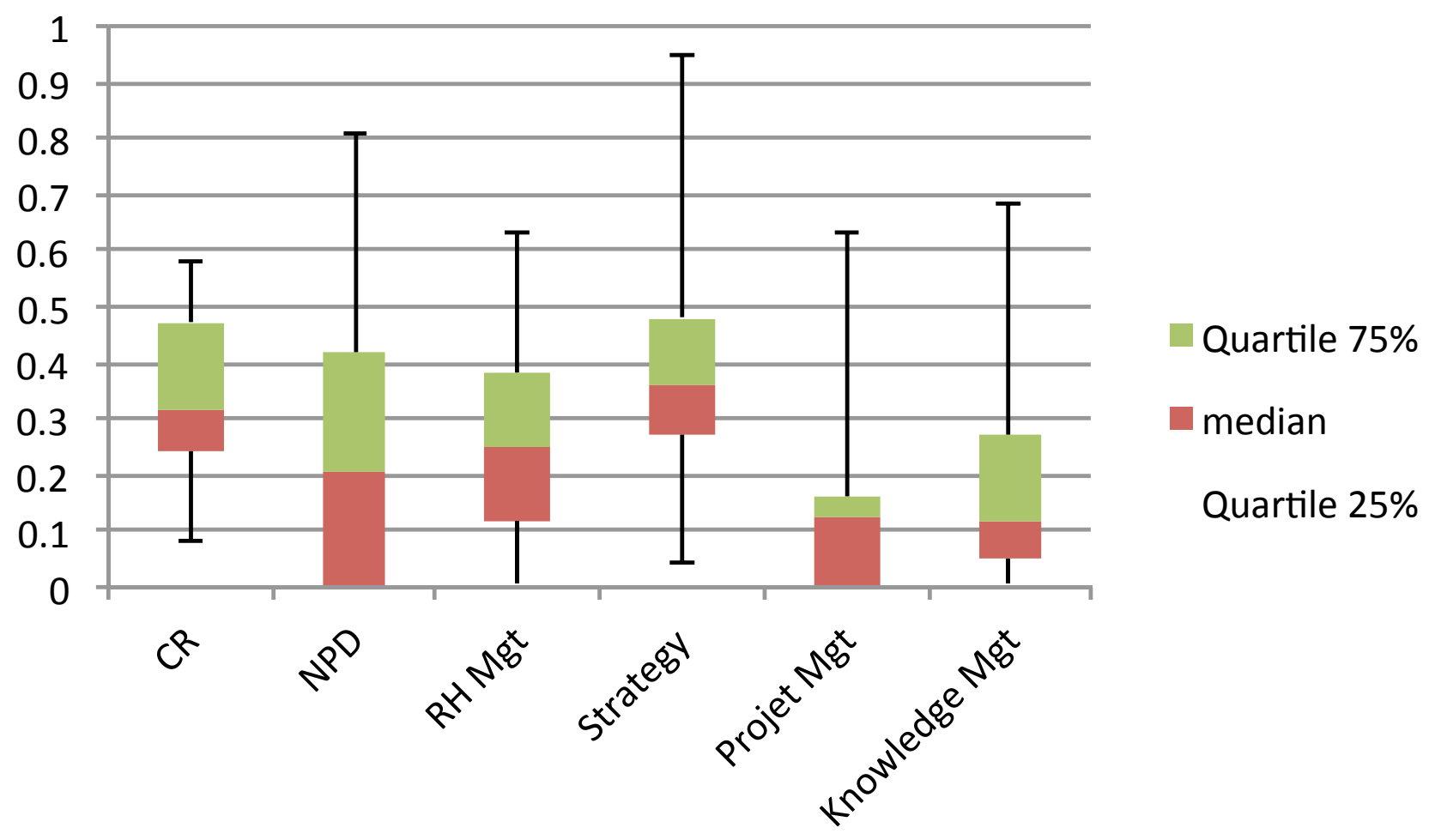

Figure 9. values for innovative practices : French sample.

ISSN: 07 I8-2724. (http://www.jotmi.org)

Journal of Technology Management \& Innovation @ Universidad Alberto Hurtado, Facultad de Economía y Negocios. 
group that stands out, because despite having a limited size they manage to be inside the group best classified.

Another important result is that if both groups are analyzed globally, there are not significant differences, since the average PII practically does not present difference between the Argentinian companies 0.262 and the French companies 0.266 , which shows a similar development in innovation on the part of the SMEs in both countries. On the other hand, if a deeper analysis is realized, we see that to achieve this level of innovation the groups of study focus on different practices. The French companies base his innovation capabilities on the strategy practice that provides more than I/3 of the strengths in innovation. While Argentine companies show a very balanced level for 6 practices evaluated in the calculation of IIP. The most noticeable differences between both groups take place in the strategy practice, where the French companies are evaluated in $45 \%$ better than their counterparts in Argentina. On the other hand, the Argentinian companies equates the IIP of the French companies, thanks to a more regular performance and to the project management practice where they overcome to the European companies in $23 \%$. In addition, the Argentinian companies show a homogeneous behavior, as there is no greater dispersion between the evaluations of the companies. When analyzing the same way the French companies the dispersion increases considerably, practically in 6 evaluated practices, this is because the group of French companies come from a more varied number of activity sectors.

This article seeks to generate the first approach for benchmarking with the innovation capabilities as a principal axis. Although this article is a study realized by only a global vision of the innovation capabilities, it shows important differences between both countries, generating new research questions for future works. Why the main difference is in strategy practice? If there are studied only companies of a sector of activity is difference minimized? These questions open a field of research that takes greater relevancy in light of the results obtained in this article.

\section{References}

ADAMS R., Bessant, J., and Phelps, R. (2006). Innovation Management Measurement: A Review. International Journal of Management Reviews 8(I): 21-47. doi: 10.1 III/j.14682370.2006.00II9.x

AKDENIZ, M., Gonzalez-Padron,T., and Calantone, R. (20I0). An Integrated Marketing Capability Benchmarking Approach to Dealer Performance through Parametric and Nonparametric Analyses. Industrial Marketing Management 39(1): 150-160. doi: 10.1016/j.indmarman.2008.05.002

ASSIELOU, N.G. (2008). Metrologie Des Processus d'Innovation. INPL.

BOLY, V. (2004). Ingénierie de L'innovation : Organisation et Méthodologies Des Entreprises Innovantes. Hermes Science Publications.

BOLY,V. (2008). Ingénierie de L'innovation : Organisation et Méthodologies Des Entreprises Innovantes. 2e édition revue et augmentée. Hermes Science Publications.

BOLY V., Morel L., Assielou G., Camargo M. (2013). Evaluating innovative processes in french firms: methodological proposition for firm innovation capacity evaluation Research Policy,(Accepted). doi: 10.1016/j.respol.2013.09.005

CAGLIANO, R., Caniato, F., Golini, R., Longoni, A., and Micelotta, E. (20II). The Impact of Country Culture on the Adoption of New Forms of Work Organization. International Journal of Operations \& Production Management $3 \mathrm{I}(3)$ : 297-323 doi: I0.1 I08/0 I44357IIIIIIII 937.

CHENG, Y.I.-L.I., and Y.U.A.N.-H.S.U. Lin (20I2). Performance Evaluation of Technological Innovation Capabilities In Uncertainty. Procedia - Social and Behavioral Sciences 40(0): 287-314.doi: 10.1016/j.sbspro.2012.03.193

CHIESA, V., Coughlan, P., and Voss, C. (1996). Development of a Technical Innovation Audit. Journal of Product Innovation Management 13(2): 105-136. doi: 10.1III/I5405885.1320105

CORONA, J. (2005). Innovation et métrologie: une approche en terme d'indice d'innovation potentielle. Thèse doctorale INPL, Nancy, France.

FEENY, S., and Rogers, M. (2003). Innovation and Performance: Benchmarking Australian Firms. Australian Economic Review 36(3): 253-264. doi: 10.1 I I I/1467-8462.00285

ISSN: 07 I8-2724. (http://www.jotmi.org) 
GARCIA, F., Martin, A., Marchetta, G., Camargo, M., Morel, L and Forradellas R. (20I2). A Framework for Measuring Logistics Performance in the Wine Industry. International Journal of Production Economics I35(I): 284-298.doi: I0. I0I6/j. ijpe.20II 08.003

GODET, M (1997). Manuel de Prospective Stratégique Dunod/APM.

GRIFFIN, A. (1997). PDMA Research on New Product Development Practices: Updating Trends and Benchmarking Best Practices. Journal of Product Innovation Management |4(6): 429-458. doi: | 0. I I I |/ |540-5885. 1460429

GUAN, J., and Ma, N. (2003). Innovative Capability and Export Performance of Chinese Firms. Technovation 23(9): 737-747.DOI: 10.1016/S0166-4972(02)00013-5

GUAN, J.C., Yam, R., Mok, C.K., and Ma, N. (2006). A Study of the Relationship Between Competitiveness and Technological Innovation Capability Based on DEA Models. European Journal of Operational Research I70(3): 97I-986.doi: 10.1016/j.ejor.2004.07.054

HENNING, T.F.P., Muruvan, S., Feng, W.A., and Dunn, R.C (20II). The Development of a Benchmarking Tool for Monitoring Progress Towards Sustainable Transportation in New Zealand. Transport Policy 18(2): 480-488. doi: 10.1016/j. tranpol.2010.10.012

HERZOG, N., Tonchia, S. and Polajnar, A. (2009). Linkages Between Manufacturing Strategy, Benchmarking, Performance Measurement and Business Process Reengineering. Computers \& Industrial Engineering 57(3): 963-975. doi: 10.1016/j.cie.2009.03.015

HUGHES, A. (200I). Innovation and Business Performance: Small Entrepreneurial Firms in the UK and the EU. New Economy 8(3): I57-163. doi: I0.1 I I I/ |468-0041.00208

HUMMELINNA, P., Peltola, S., Tuimala, J., and Virolainen, V.M. (2002). Attaining World-class R\&D by Benchmarking Buyersupplier Relationships. International Journal of Production Economics 80(I):39-47.doi: 10.1016/S0925-5273(02)0024I4

IGARTUA, J., Garrigós, J. and Hervas-Oliver, J. (2010). How Innovation Management Techniques Support an Open Innovation Strategy. Research-Technology Management 53(3): $4 I-52$.
JARRAR, Y., and Zairi, M. (200I). Future Trends in Benchmarking for Competitive Advantage: A Global Survey. Total Quality Management 12(7-8): 906-912.doi: 10.1080/09544I20100000014

LAI, Mei-Chi, Hao-Chen Huang, and Wei-Kang Wang (20I I). Designing a Knowledge-based System for Benchmarking: A DEA Approach. Knowledge-Based Systems 24(5): 662-67I. doi: 10.1016/j.knosys.2011.02.006

LOVE,J., Roper,S.and Bryson,J.(20I I). Openness, Knowledge, Innovation and Growth in UK Business Services. Research Policy 40(10): I438-I452. doi: I0.10 I6/j.respol.20 I I.05.016

McADAM, R., Moffett, S., Hazlett, S.A., and Shevlin, M. (2010). Developing a Model of Innovation Implementation for UK SMEs: A Path Analysis and Explanatory Case Analysis. International Small Business Journal 28(3): 195-214. doi: I0.1 I77/0266242609360610

MILBERGS, E. (2004). Innovation Metrics: Measurement to Insight. National Innovation Initiative $21^{\circ}$ Century Innovation Working Group Chair, Nicholas M. Donofrio, IBM Corporation.

MOREL, L., and V. Boly (2008). Innovation Process Evaluation: From Self-assessment to Detailed Technological Audit. In Management Of Technology Innovation And Value Creation-. M. Sherif and T. Khalil, eds. World Scientific Publishing Co. Pte. Ltd. doi: I0.1 I 42/97898 | 2790545_0023

MOREL, L., and Camargo, M. (2006). Comparison of multicriteria analysis techniques to improve the innovation process measurement. In - P. 8 p. - @Proceeding. BEIJING, Chine.

MULLER, A., Välikangas, L., and Merlyn, P. (2005). Metrics for Innovation: Guidelines for Developing a Customized Suite of Innovation Metrics. Strategy \& Leadership 33(I): 37-45.doi: I0.1 108/10878570510572590

NEMERY, P., Ishizaka, A., Camargo, M., and Morel, L. (20I2). Enriching Descriptive Information in Ranking and Sorting Problems with Visualizations Techniques. Journal of Modelling in Management 7(2): 130-147.doi: I0.1 I08/I746566/2| I 242778

PHYLIPSEN, D., Blok, K., Worrell, E., and de Beer, J. (2002). Benchmarking the Energy Efficiency of Dutch Industry: An Assessment of the Expected Effect on Energy Consumption and CO2 Emissions. Energy Policy 30(8): 663-679.doi: I0.1016/S030|-42I5(02)00023-X 
RADNOR, Z., and Robinson, J. (200I). Benchmarking Innovation: A Short Report. SSRN Scholarly Paper, ID 233348. Rochester, NY: Social Science Research Network. doi: I0.1III/|467-869|.00153

REJEB, H,B., Morel-Guimarães, L., Boly, V., and Assiélou, N.G. (2008). Measuring Innovation Best Practices: Improvement of an Innovation Index Integrating Threshold and Synergy Effects. Technovation 28(12): 838-854 doi: 10.1016/j.technovation.2008.08.005.

RIZET, C., Browne, M., Cornelis, E., and Leonardi,J. (20I2).Assessing Carbon Footprint and Energy Efficiency in Competing Supply Chains: Review - Case Studies and Benchmarking. Transportation Research Part D:Transport and Environment 17(4): 293-300.doi: 10.1016/j.trd.2012.01.002

RODRIGUES, C., Fernandes, E., and F. Martins, V. (2006). Innovativeness and Network Competence : an Integration and Empirical Examination. International Product Development Management Conference, 13, Milano

ROPER, S., and Arvanitis, S. (20/2). From Knowledge to Added Value: A Comparative, Panel-data Analysis of the Innovation Value Chain in Irish and Swiss Manufacturing Firms. Research Policy 4I(6): 1093-I106.doi: 10.1016/j.respol.20I2.03.002

RORISSA, A., Demissie, D., and Pardo, T. (20II). Benchmarking e-Government: A Comparison of Frameworks for Computing e-Government Index and Ranking. Government Information Quarterly 28(3): 354-362.doi: 10.1016/j. giq.2010.09.006

ROSENBUSCH, N., Brinckmann, J., and Bausch, A. (20II). Is Innovation Always Beneficial? A Meta-analysis of the Relationship Between Innovation and Performance in SMEs. Journal of Business Venturing 26(4): 44I-457.doi: 10.1016/j. jbusvent.2009.12.002

SEPULVEDA, J., Gonzalez, J., Camargo, M., and Alfaro, M. (2010). A Metrics-based Diagnosis Tool for Enhancing Innovation Capabilities in SMEs. International Journal of Computers, Communications and Control 5(5): Pages 919-928.

WOMACK, J.P., Jones, D., and Roos, D. (2007). The Machine That Changed the World: The Story of Lean production-Toyota's Secret Weapon in the Global Car Wars That Is Revolutionizing World Industry. New York: Free Press.
YOGUEL, G., Boscherini, F., and NU. CEPAL. Oficina en Buenos Aires (1996). La Capacidad Innovativa y El Fortalecimiento de La Competitividad de Las Firmas: El Caso de Las Pymes Exportadoras Argentinas. Documento de Trabajo, $n$. 71. Buenos Aires: NU. CEPAL. Oficina en Buenos Aires.

ZAWISLAK, P., Cherubini Alves, A., Tello-Gamarra, J., Barbieux, D., and Maciel Reichert, F. (20I2). Innovation Capability: From Technology Development to Transaction Capability. Journal of Technology Management \& Innovation 7(2): |4-27.doi: 10.4067/s07/8-272420|2000200002

ZAWISLAK, P., and Manhães Marins, L. (2007).

Strenghtening Innovation in Developing Countries. Journal of Technology Management \& Innovation 2(4): 44-54. 